\title{
Technological Characterization and Use of Babassu Residue (Orbygnia phalerata Mart.) in Particleboard
}

\author{
Nítalo André Farias Machado ${ }^{1}$, Hosana Aguiar Freitas de Andrade ${ }^{1}$, Luisa Julieth Parra-Serrano ${ }^{1}$, \\ Marileia Barros Furtado ${ }^{1}$, Raíssa Rachel Salustriano da Silva-Matos ${ }^{1}$, Maryzélia Furtado de Farias ${ }^{1}$ \\ \& Jomar do Livramento Barros Furtado \\ ${ }^{1}$ Federal University of Maranhão (UFMA), Chapadinha, Brazil \\ Correspondence: Luisa Julieth Parra-Serrano, Federal University of Maranhão, CCAA-UFMA, MA-230, km 04, \\ s/n, Boa Vista, 65500-000, Chapadinha, Maranhão, Brazil. Tel: 55-983-471-1201. E-mail: \\ julieth_ps@yahoo.com
}

$\begin{array}{lc}\text { Received: July 1, } 2017 & \text { Accepted: August 10,2017 } \quad \text { Online Published: September 15, } 2017 \\ \text { doi:10.5539/jas.v9n10p47 } & \text { URL: https://doi.org/10.5539/jas.v9n10p47 }\end{array}$

The research is financed by FAPEMA.

\begin{abstract}
The wood-based panel industry is growing all over the world, and in many countries the raw material is becoming increasingly inadequate and increasingly expensive. Therefore, new inputs are needed to reduce production costs. The residue of babassu palm fruit after nut extraction process is an alternative, due to its fibrous characteristics, the high availability in the large agroindustrial complexes in the North of Brazil and the low cost. Thus the research was: (i) to determine the mechanical characteristics (tensile strength and elasticity), physicochemical characteristics (density, $\mathrm{pH}$, extractives content and chemical composition) and micro-structural of the babassu residue, comparing it with the particles of Pinus sp., used in commercial panels; (ii) to evaluate the quality of panels manufactured with babassu residue by physical conditions (swelling in thickness and water absorption) and mechanical characterization (elasticity and rupture) based on Brazilian Technical Standards (NBR 14810-2: 2013), American (ANSI A208.1: 2009) and European (EN 312: 2003). Statistical analysis of the data was performed with the aid of Infostat software through analysis of variance using Tukey test at the 5\% probability level. The babassu residue has technological characteristics that allow its use in particleboard production. However, there are particularities that may compromise its use, such as high silica content and high density. Particleboard made from babassu residue presented mechanical performance above that required by current normative documents. However, for the physical properties, especially for the porosity of the particleboard of babassu, the obtained values were lower than the required minimum.
\end{abstract}

Keywords: alternative inputs, wood panels, new products, sustainability

\section{Introduction}

The babassu palm (Orbygnia phalerata Mart.) is considered to be one of the most important Brazilian palm, especially because it is one of the most abundant palms in the pre-Amazon region, and for its relevant socioeconomic contribution of northern Brazil (Queiroga et al., 2015). However, the use of babassu nut is based on the exploitation of your nuts, which represents only 7\% of the fruit (Soler et al., 2007).

From the remaining $93 \%$ of the fruit after the extraction process, $13 \%$ corresponds to the epicarp the outermost part of the fruit, which has a high proportion of fibers; $20 \%$ to the mesocarp, intermediate portion which has a high content of starch and $60 \%$ to the endocarp, a portion that surrounds the nuts, which presents more woody characteristics. This material is considered waste. It is generally used as biomass for the production of energy (Almeida et al., 2002).

According to the Brazilian Institute of Geography and Statistics (IBGE), nut extraction of babassu nut in the year of 2015 reached 77,955 tons, representing a residual amount of 168,902 tons of epicarp, 22,728 tons of mesocarp and 668,185 tons of endocarp of babassu. As a result, forest industry researchers have started efforts to use the residuals as raw material for the production of particleboard (Iwariki et al., 2004). 
Recent research has used residues in particleboard, such as: peanut shell (Arachis hypogaea) (Gatani et al., 2013), residues of Coconut-green (Cocos nucifera L.) (Fiorelli et al., 2015; Baldin et al., 2016) and sugarcane bagasse (Saccharum officinarum L.) (Soares et al., 2017), adding value to these residues and avoiding environmental damage.

The market for particleboard is gaining more and more space because they are products of wide versatility and they can be used in the construction industry, furniture, shipbuilding, construction for agriculture and construction industries (Mendes et al., 2010; Belini et al., 2014). The application of agro-industrial residues as an input of these products is possible due to the chemical similarity with the wood, especially the hardwoods that have lower lignin content and higher pentosan hemicellulose content (Iwakiri et al., 2004).

However, it is not any residue that, when used, provides a satisfactory technological performance to the final product, since the physical-mechanical, physicochemical and micro-structural characteristics of the raw material directly influence and are fundamental parameters to define the potentialities and limitations of use (Belini et al., 2014). Therefore, the knowledge of the mechanical, chemical and anatomical characteristics of fibrous residues are important in the decision of making process to determine the specific design of the composites, optimizing the quality and reducing processing costs.

In this context, considering the lack of information, the objective of this study was to evaluate the mechanical, physic-chemical and micro-structural characteristics of the epicarp-endocarp residual complex of babassu coconut, and to evaluate the quality of particleboard based on the epicarp-endocarp residue of babassu coconut considering the Brazilian technical norms (NBR 14810-2: 2013), the American technical norms (ANSI A208.1: 2009) and the European ones (EN 312: 2003), comparing them with particleboard manufactured with commercial particles.

\section{Materials and Method}

\subsection{Collection of Samples}

Samples of the babassu coconut residue were obtained after the cocoa bean extraction process was carried out in associations of "Babassu Coconut Breakers" in the city of Vargem Grande, Maranhão, Brazil ( $3^{\circ} 32^{\prime} 36^{\prime \prime}$ S and $43^{\circ} 55^{\prime} 6^{\prime \prime} \mathrm{W}$ ). The particles of Pinus sp. were supplied by a furniture industry located in the region of Macatuba, São Paulo, Brazil $\left(22^{\circ} 29^{\prime} 58^{\prime \prime}\right.$ S and $48^{\circ} 43^{\prime} 3^{\prime \prime}$ W). The residues were washed in running water in a solution of neutral soap and water and submitted to natural drying for 24 hours, and later sent to the Laboratory of Rural Constructions and Ambience in the Department of Bio-systems Engineering of the Faculty of Animal Science and Food Engineering (FZEA) from the University of São Paulo (USP), in Pirassununga, São Paulo, Brazil.

\subsection{Physical and Chemical Analyzes of Samples}

The determination of the actual density was obtained by pycnometry using the Quantachorome Instruments Multi Helium Picnometer, model MVP 5DC. Initially the samples were weighed in an analytical balance with an accuracy of $0.0001 \mathrm{~g}$ to obtain the dry mass, then the respective volumes were obtained for each sample by means of Equation 1, using the values provided by the Multi Picnometer, The actual density of the samples using Equation 2.

$$
V_{p}=V_{c}-V_{r}\left[\left(\frac{P_{1}}{P_{2}}\right)-1\right]
$$

Where,

$V_{p}$ : Sample volume $\left(\mathrm{cm}^{3}\right) ; V_{c}$ : Volume of the small cell of the apparatus $\left(\mathrm{cm}^{3}\right) ; V_{r}$ : Volume of the instrument reference $\left(\mathrm{cm}^{3}\right) ; P_{1}$ : Pressure measured after pressurizing the reference volume (Psi); $P_{2}$ : Pressure measured after inclusion of the cell volume of the apparatus (Psi).

Where,

$$
D=\frac{M_{s}}{V_{p}}
$$

Ad: Actual density $\left(\mathrm{g} / \mathrm{cm}^{3}\right)$; Dm: Dry mass of sample $(\mathrm{g}) ; V_{p}$ : Sample volume $\left(\mathrm{cm}^{3}\right)$.

The determination of the hydrogenation potential $(\mathrm{pH})$ was performed by the potentiometer method, using DM-23 pHmeter composed of thermocouple and flow-type electrode Digimed model DME-CV1. The extractive contents were obtained by the Soxhlet method, which basically consists of three steps: extraction of the fat from the sample with solvent, elimination of the solvent by evaporation and calculation of the extracted fat (IAL, 
1985). The determination of the structural chemical components of the samples was performed according to the methodology described by Silva and Queiroz (2006).

\subsection{Microstructural Analysis}

Microstructural analysis was performed using images obtained by Scanning Electron Microscopy (SEM). For this, the samples were fixed in metallized support to prevent the incident electrons from being absorbed by the samples, and packed in hermetically sealed packages and examined under SEM, model Quanta 400.

The images were obtained in several enlargements that were better adapted to the objective of study and visualization. Analyzes of elemental chemical composition were carried out by the Energy Dispersive Spectroscopy (EDS) supplement, coupled to the SEM. During the analyzes the high vacuum mode was used, with partial pressure of $1.33 \mathrm{mbar}$ and acceleration voltage $2 \mathrm{kV}$ for the acquisition of images and $30 \mathrm{kV}$ for the analysis of elemental chemical composition.

\subsection{Mechanical Analysis of Samples}

The residual samples ( $80 \mathrm{~mm}$ dimension) were submitted to the parallel traction test in the Universal Testing Machine (EMIC), according to the methodology described by Motta and Agopyan (2007). A load cell of $1 \mathrm{kN}$, velocity $0.4 \mathrm{~mm} \mathrm{~min}^{-1}$, length between $20 \mathrm{~mm}$ claws and pressure of the pneumatic claws of $200 \mathrm{kgf}$ was used. The tensile strength and modulus of elasticity of the samples were determined from Equations 3 and 4, respectively.

$$
\begin{gathered}
T_{\max }=\frac{F_{\max }}{A} \\
M O E=\frac{T_{1}-T_{2}}{D_{e 1}-D_{e 2}}
\end{gathered}
$$

Where,

$T_{\max }$ : tensile strength (MPa); $F_{\text {max }}$ : maximum stress preceding the rupture of the specimen $(\mathrm{N}) ; A$ : cross-sectional area of the specimen $\left(\mathrm{mm}^{2}\right) ; M O E$ : modulus of elasticity (MPa); $T_{1}$ : Maximum voltage obtained within the linear region, in the strain $\times$ strain curve $(\mathrm{MPa}) ; T_{2}$ : Minimum voltage obtained within the linear region, in the strain $\times$ strain curve $(\mathrm{MPa}) ; D_{\mathrm{e} 1}$ : Maximum deformation obtained within the linear region, in the stress $\times$ strain (dimensionless) curve; $D_{\mathrm{e} 2}$ : Minimum deformation obtained within the linear region, in the strain $\times$ strain (dimensionless) curve.

\subsection{Manufacture of the Particleboard}

High density particleboard $\left(660 \mathrm{~kg} \mathrm{~m}^{-3}\right.$ to $\left.680 \mathrm{~kg} \mathrm{~m}^{-3}\right)$ whith nominal dimensions of $400 \times 400 \times 10 \mathrm{~mm}$ were produced using babassu residue particles and Pinus sp particles were produced using babassu residue particles and Pinus sp. particles, commonly used in commercial particleboard. The manufacturing process followed the recommendations detailed by Paes et al. (2011). Initially, the raw material was dried at room temperature until it reached a moisture content varying from 3 to $8 \%$, minced in hammer mill, and classified in a vibrating screen with $8.0 \mathrm{~mm}$ and $4.0 \mathrm{~mm}$ mesh and $<4.0 \mathrm{~mm}$ (Collector), obtaining particles with grading of $8.0>4.0 \mathrm{~mm}$. The particles, already processed, were placed in a planetary mixer for homogenization with the bi-component resin based on castor oil in the content of $12 \%$ based on the dry weight of the particles. Thereafter, the already homogenized material was inserted into a forming mold, and the formed particle mattress was inserted in a thermo-hydraulic press, with a temperature of $100{ }^{\circ} \mathrm{C}$ for 10 minutes at a mean pressure of $5 \mathrm{MPa}$. After pressing, the particulate composites produced were stored at room temperature for 72 hours to allow complete curing of the resin.

\subsection{Quality Analyzes of the Particleboard Produced}

The evaluation of the quality of the particleboard was carried out by means of their physical-mechanical characterization, taking as reference the values recommended by the Technical Standards: NBR 14810-2: 2013; ANSI A208.1: 2009 and EN 312: 2003. The use of these standards is justified by the fact that they are the commercial standards of particleboard.

The physical characterization tests were: swelling in thickness after 2 hours (IE $2 \mathrm{~h}$ ) and 24 hours (IE $24 \mathrm{~h}$ ) and water absorption after 2 hours (Abs $2 \mathrm{~h}$ ) and $24 \mathrm{~h}$ (Abs $24 \mathrm{~h}$ ), performed on bodies of $25 \times 25 \times 14 \mathrm{~mm}$ dimensions, inserted in a vessel with distilled water at $20^{\circ} \mathrm{C}$, with water level $25 \mathrm{~mm}$ above the upper surface of the test bodies (CPs). 
The swelling in thickness consists of the difference of the thickness before and after the immersion of the CPs in water. Measurements were performed using a digital caliper with a $0.001 \mathrm{~mm}$ accuracy. The water absorption consisted of the weight difference before and after the immersion of CPs in water in a period of 2 and 24 hours. The weighing was carried out in an analytical balance with a resolution of $0.001 \mathrm{~g}$.

The mechanical characterization tests were: modulus of rupture (MOR) and modulus of elasticity (MOE); Obtained by means of three-point static bending in the universal testing machine, operating with a load cell of 0.5 tons, execution speed of $7 \mathrm{~mm} \mathrm{~min}^{-1}$ and a distance between points of $200 \mathrm{~mm}$. CPs with dimensions of 250 $\times 50 \times 14 \mathrm{~mm}$ were used. The calculation procedures were performed in accordance with Technical Standard NBR: 14810 (ABNT, 2006).

\subsection{Statistical Analyzes}

The exploratory analysis of the data was performed using Infostat software, through analysis of variance (ANOVA), the factors in each response-variable were investigated. The variance homogeneity test (Bartlett test, $5 \%$ significance) and normality (Shapiro-Wilk test, $5 \%$ of significance) were performed prior to analysis of variance. The variables of interest were compared using the Tukey test at the $95 \%$ confidence level.

\section{Results and Discussion}

\subsection{Characterization of the Babassu Residue}

The babassu residue has high density $\left(1030 \mathrm{~kg} \mathrm{~m}^{-3}\right)$, which may represent limitations in the process of densification and consolidation of the particleboard, especially in the efficiency in the adhesive bonding with the particles in the structural system due to the high compaction ratio (Table 1). According to Maloney (1996), raw materials with a density of up to $550 \mathrm{~kg} \mathrm{~cm}^{-3}$ are ideal because they reach a compression ratio between 1.3 and 1.6. The high value of real density can be justified by the presence of the endocarp of babassu, a more woody portion of the fruit. However, in relation to $\mathrm{pH}$, a similar average value was found for the wood used in the production of particulate composites, which varies from 3.0 to 5.5 (Fiorelli et al., 2014), very acidic raw materials can inhibit chemical reactions in the Curing resin, impairing binding in the structural system (Iwariki et al., 2012).

Table 1. Average values of real density (RD), hydrogenation potential $(\mathrm{pH})$, extractive content (EC), lignin, cellulose and hemicellulose of the epicarp-endocarp residue particles of babassu and Pinus sp.

\begin{tabular}{lllllll}
\hline Particles & $\mathrm{RD}\left(\mathrm{kg} \mathrm{m}^{-3}\right)$ & $\mathrm{pH}$ & $\mathrm{EC}(\%)$ & Lignin $(\%)$ & Cellulose $(\%)$ & Hemicellulose $(\%)$ \\
\hline Residue & $1030 \mathrm{~A}$ & $5.35 \mathrm{~A}$ & $1.12 \mathrm{~B}$ & $33.62 \mathrm{~A}$ & $32.28 \mathrm{~B}$ & $27.86 \mathrm{~A}$ \\
$\mathrm{CV}(\%)$ & 1.95 & 1.25 & 0.80 & 2.80 & 3.72 & 3.40 \\
Pinus sp. & $480 \mathrm{~B}$ & $4.62 \mathrm{~B}$ & $3.32 \mathrm{~A}$ & $24.82 \mathrm{~B}$ & $52.42 \mathrm{~A}$ & $20.20 \mathrm{~B}$ \\
$\mathrm{CV}(\%)$ & 2.15 & 1.22 & 1.15 & 2.36 & 3.80 & 2.53
\end{tabular}

Note. $\mathrm{CV}=$ Coefficient of variation. Means followed by the same letter in the column do not differ by Tukey test at $5 \%$ probability.

Although it is an oleaginous palm tree, the analysis of total extractives showed a low average value, this result indicates optimal conditions for application in particleboard, because, high levels of extractives block the contact of the adhesive with the particles of the structural system in the process of Bonding of the composite (Bufalino et al., 2012). This result is justified by the physical barrier corresponding to the brown integument that surrounds the babassu coconut almond, which concentrates commonly the extractives, and by the high concentration of silica that is related to the protection of the fruit (Machado et al., 2015), especially against fungi, As can be observed in Figure 1, which highlights the presence of clusters of silica crystals (silicon dioxide or silica, $\mathrm{SiO}_{2}$ ) under the cellular components of the babassu residue identified in the SEM image and chemically proven by Energy Dispersive Scan (EDS) (Table 2). 


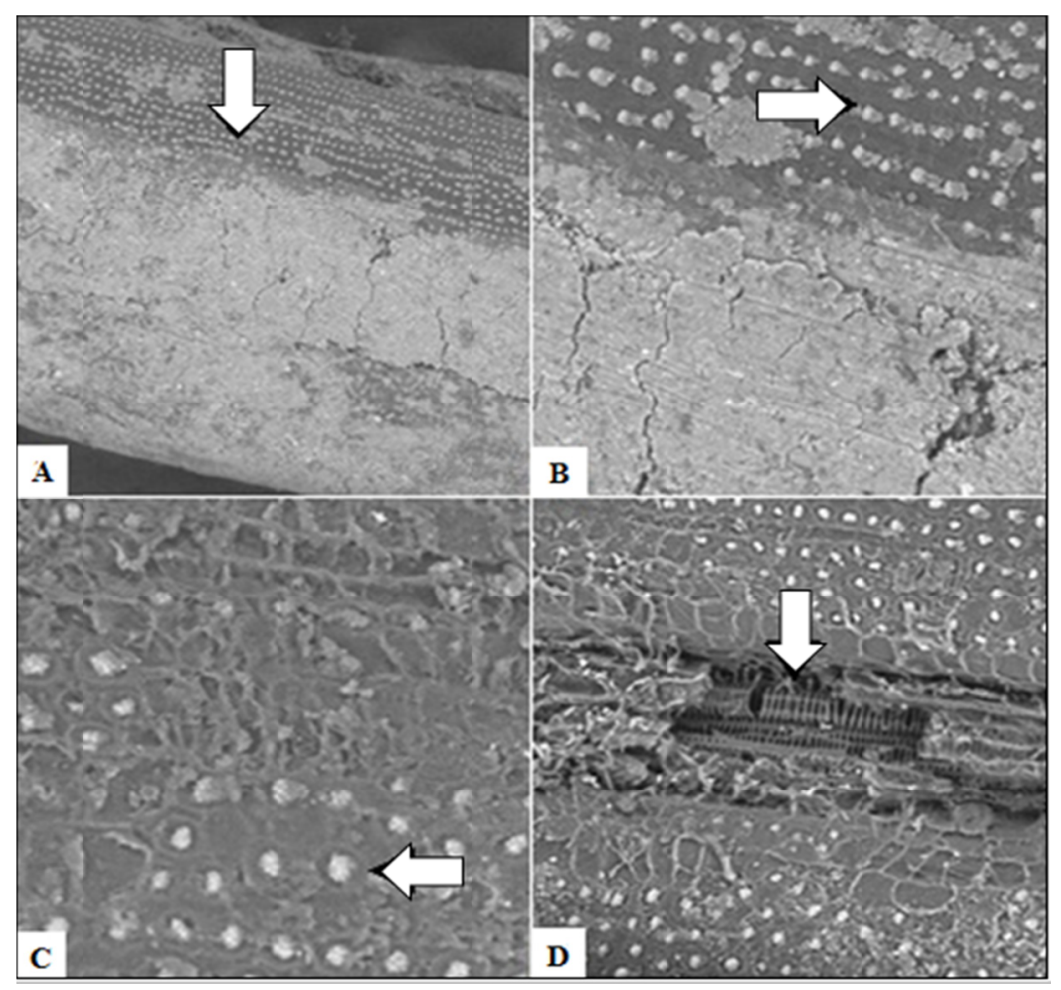

Figure 1. Silica crystals $(500 \mu \mathrm{m})(\mathrm{A})$, magnification at $200 \mu \mathrm{m}$ (B) and $100 \mu \mathrm{m}$ (C) and emphasis on the fibrous structure tracheid format $(200 \mu \mathrm{m})(\mathrm{D})$

Table 2. Elemental chemical composition of the epicarp-endocarp residue of babassu obtained by probe energy dispersive scan

\begin{tabular}{llll}
\hline Element & Weight $\%$ & Weight $\% \sigma$ & Atomic $\%$ \\
\hline Carbon & 56.651 & 0.386 & 64.160 \\
Oxygen & 40.634 & 0.375 & 34.549 \\
Magnesium & 0.069 & 0.022 & 0.039 \\
Aluminum & 0.085 & 0.020 & 0.043 \\
Silicon & 2.272 & 0.041 & 1.101 \\
Sulfur & 0.083 & 0.020 & 0.035 \\
Chlorine & 0.065 & 0.021 & 0.025 \\
Potassium & 0.140 & 0.022 & 0.049 \\
\hline
\end{tabular}

Because it is an organic compound, the babaçu residue is composed of a high content of carbon and oxygen, with silica being the third element with higher concentration, which can be attributed to the fact in the superior vegetables, such as babassu palm, silica is a beneficial element, it acts on the rigidity to the vegetal structures, helping in the photosynthetic uptake and the resistance to pests and attacks of fungi (Machado et al., 2015).

It is important to note that in addition to the natural origin of silica in the babassu residue, contamination may occur during the collection, transportation, extraction and storage of the residues. The high concentration of silica in the raw material of particleboard is an undesirable characteristic because it increases the wear of cutting and processing equipment of the particulate composites (Belini et al., 2014).

In relation to the lignin, cellulose and hemicellulose contents, it is possible to observe a similarity with the contents of Pinus sp. It is possible to verify higher cellulose content $(\mathrm{p} \leq 0.05)$ in the Pinus sp. The content of cellulose is closely related to the mechanical properties of the panel, and therefore its quality. However, the lignin content is higher in the babassu residue, which, according to Bufalino et al. (2012) facilitates adhesion mechanisms by acting as a buffer for cellulose micro-fibrils, limiting parallel movement to the grain, which may benefit the Adhesion of the particles. 
It is worth mentioning that the xylem of the babassu residue is constituted by support cells with bundles of fibers arranged in spiral-type tracheid (Figures 2A, 2B and 2C), the vessels having a mean thickness of $11.6 \mu \mathrm{m}$ and the fibers average length of $5 \mathrm{~cm}$ (Figure 2D), these characteristics relate to the arrangement of structural lignin. It is known that the choice of inputs for the manufacture of particleboard depends on the type of the final product and its application, however, particles with shorter fibers and with thicker cell wall and longer tracheid length favors the conditions of formation of the (Iwakiri et al., 2004), as is the case with the babassu residue.

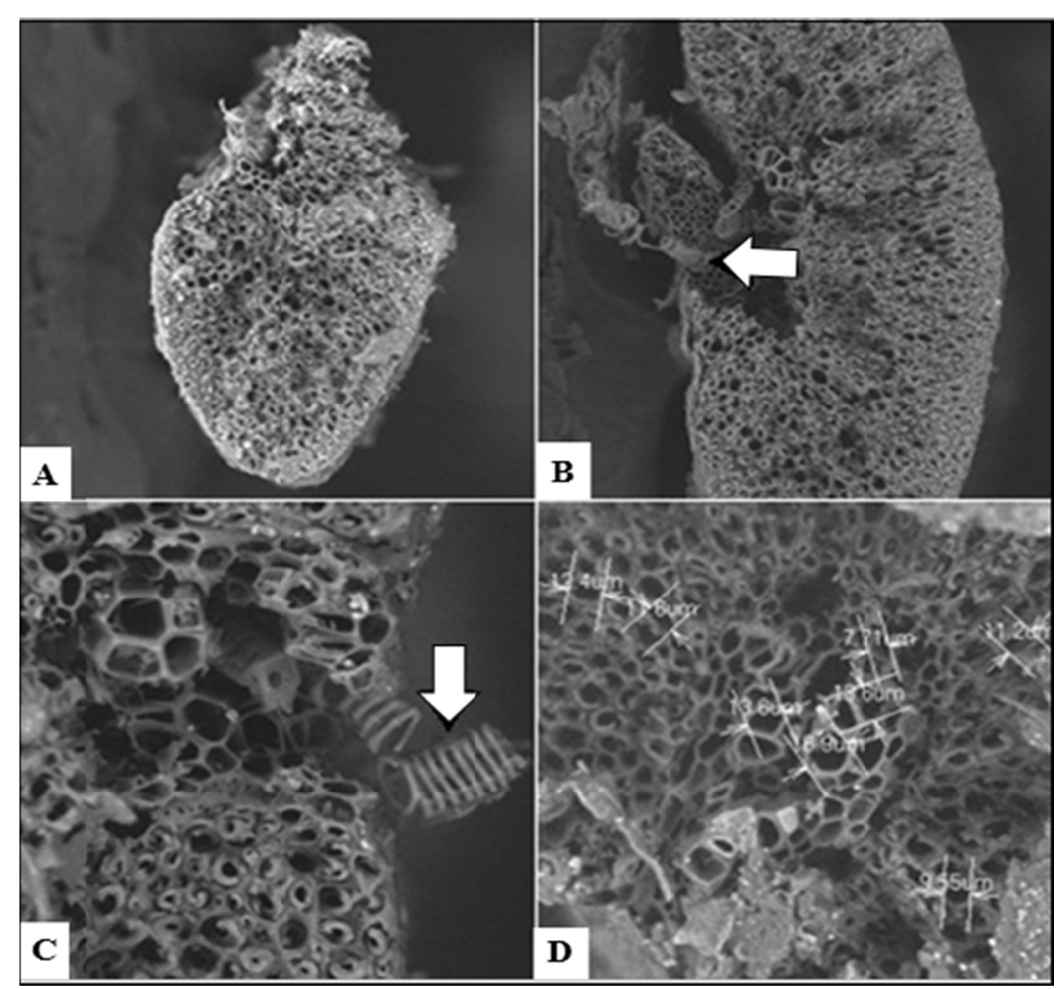

Figure 2. Cross-sectional view of the babassu residue $(300 \mu \mathrm{m})(\mathrm{A})$, spiral tracheal element $(200 \mu \mathrm{m})(\mathrm{B})$, magnified at $100 \mu \mathrm{m}(\mathrm{C})$ and vessel elements (D)

Very short fibers have increased total surface area, which represents higher resin consumption, but these fibers present high machining quality, particles with longer fibers, such as particles with babassu residue, usually cause problems in the formation of the mattress (Park et al., 1998). However, the babassu residue has thin cell walls, a characteristic that may facilitate the defibration due to the greater area of contact and what contributes to the strengthening of bonds of the type hydrogen bonds.

There was no difference $(\mathrm{p} \leq 0.05)$ in the modulus of elasticity (MOE) between the particles of the babassu residue and the particles commonly used in commercial panels (Pinus sp.), Being smaller in the particles of the babassu residue, which means that there is a greater possibility of cracking openings, for a same level of request of the fiber-matrix assembly, in panels based on this residue (Table 3).

Table 3. Mean values of the mechanical characteristics of tensile strength (TS) and modulus of elasticity (MOE) of the residual particles and Pinus sp.

\begin{tabular}{lll}
\hline Particle & TS (MPa) & MOE (MPa) \\
\hline Babassu Residue & $50.40 \mathrm{~A}$ & $1464.72 \mathrm{~B}$ \\
& $\mathrm{CV}: 2.10 \%$ & $\mathrm{CV}: 6.50 \%$ \\
\hline Pinus sp. & $49.60 \mathrm{~A}$ & $5630.80 \mathrm{~A}$ \\
& $\mathrm{CV}: 3.20 \%$ & $\mathrm{CV}: 4.40 \%$ \\
\hline
\end{tabular}

Note. $\mathrm{CV}=$ Coefficient of variation. Means followed by the same letter in the column do not differ by Tukey test at $5 \%$ probability. 


\subsection{Physical-Mechanical Characterization of Fabricated Particleboard}

When particleboard are exposed to moisture, they may change, and in some cases, the magnitude of this phenomenon is a limiting factor for their use. The results of swelling in thickness after 2 and 24 hours of submersion in water (IE $2 \mathrm{~h}$ and IE $24 \mathrm{~h}$ ) indicate significant gains of swelling $(\mathrm{p} \leq 0.05)$ when the babassu residue was used (Table 4). As well as, a greater water absorption (Abs $2 \mathrm{~h}$ and Abs $24 \mathrm{~h}$ ), being verified a significant difference after 24 hours of submersion in water.

Table 4. Average values of swelling thickness in 2 (IE $2 \mathrm{~h}$ ) and 24 (IE $24 \mathrm{~h}$ ) hours and water absorption in 2 (Abs $2 \mathrm{~h}$ ) and 24 hours (Abs $24 \mathrm{~h}$ ) of the manufactured particleboards

\begin{tabular}{lllll}
\hline Particleboard & IE 2 h (\%) & IE 24 h (\%) & Abs 2 h (\%) & Abs 24 h (\%) \\
\hline 100\% Residue & $28.60 \mathrm{~A}$ & $46.20 \mathrm{~A}$ & $28.55 \mathrm{~A}$ & $66.82 \mathrm{~A}$ \\
$\mathrm{CV}(\%)$ & 8.20 & 12.60 & 7.40 & 13.20 \\
$100 \%$ Pinus sp. & $7.82 \mathrm{~B}$ & $32.28 \mathrm{~B}$ & $26.26 \mathrm{~A}$ & $52.48 \mathrm{~B}$ \\
$\mathrm{CV}(\%)$ & 7.40 & 10.80 & 6.30 & 14.60 \\
\hline Normatives & IE 2 h (\%) & IE 24 h (\%) & Abs 2 h (\%) & Abs 24 h (\%) \\
\hline ANSI A208.1 & 8 & 20 & & \\
NBR 14810-2 & 8 & 20 & & \\
EN 312 & 8 & & & \\
\hline
\end{tabular}

Note. $\mathrm{CV}=$ Coefficient of variation. Means followed by the same letter in the column do not differ by Tukey test at $5 \%$ probability.

In general, the use of the babassu residue provided lower performance than the minimum values recommended for the IE test by the European Technical Standard-EN (2003), Brazilian NBR-ABNT (2013) and American ANSI A208.1 (2009). However, the literature indicates some strategies that can reduce water absorption and swelling, such as the application of waterproofing agents (adhesives or paraffin) that block the absorption sites (Fiorelli et al., 2011) or the thermal treatment of particles, since Which strengthens the dimensional stability of the composite due to the degradation of the hemicellulose, which releases the compression stress formed during pressing (Carvalho et al., 2015).

The physical behavior of the panels can be attributed to the high density of the babassu residue, especially to the portion of the endocarp, since particles with high density provide a smaller surface of contact increasing the porosity of the panel; which increases the voids in the structural system promoting greater water intake. In addition, the high hemicellulose content in the babassu residue, as can be seen in Table 1, increases the hygroscopicity of the composite and raises the penetration rate of the water molecules in the submicroscopic spaces between the micro-fibrils, which negatively influences adhesion between micro-fibrils (Melo, 2013), providing a low compression ratio.

In the literature, similar results are found in particleboard produced with Pinus elliottii particles and babassu epicarp at the $30 \%$ incorporation level using urea-formaldehyde resin, with mean IE values at 2 and $24 \mathrm{~h}$ of 32.10 and $37.86 \%$ and abs in 2 and $24 \mathrm{~h}$ of 80.82 and $90.04 \%$, respectively (Lima et al., 2006), and in particleboard produced from peanut shell residues with urea-Formaldehyde, with IE values at 2 and 24 hours at 16 and $50 \%$ and Abs at 2 and 24 hours at $29 \%$ and $70 \%$ (Gatani et al., 2013).

The particleboard manufactured with babassu residue showed lower modulus of rupture (MOR) and modulus of elasticity (MOE) in relation to panels composed of particles of Pinus sp. However, it is important to note that all panels are above the requirements for MOR by the European Technical Standards-EN (2003), Brazilian-ABNT (2013) and American ANSI (2009) (Table 5). The fibrous consistency of the babassu residue and its high tensile strength (Table 3) may be the main factors responsible for this performance. However, the high density of this raw material makes it difficult to obtain a satisfactory volume for pressing the panel during the manufacturing process, which conditions the product a greater porosity and substantially increases the swelling and water absorption values, and consequently mechanical performance due to low dimensional stability. 
Table 5. Mean values of modulus of rupture (MOR) and modulus of elasticity (MOE) of the manufactured particleboard

\begin{tabular}{lll}
\hline Particleboard & MOR $(\mathrm{MPa})$ & MOE $(\mathrm{MPa})$ \\
\hline $100 \%$ Resíduo & $23.40 \mathrm{~B}$ & $2,320.00 \mathrm{~B}$ \\
CV $(\%)$ & 14.64 & 14.00 \\
$100 \%$ Pinus sp. & $32.30 \mathrm{~A}$ & $2,960.00 \mathrm{~A}$ \\
CV $(\%)$ & 12.52 & \\
\hline Normatives & MOR $(\mathrm{MPa})$ & $\mathrm{MOE}(\mathrm{MPa})$ \\
\hline ANSI A208.1 & 13.00 & $2,000.00$ \\
NBR $14810-2$ & 11.00 & $1,600.00$ \\
EN 312 & 13.00 & $1,200.00$
\end{tabular}

Note. $\overline{\mathrm{CV}}=$ Coefficient of variation. Means followed by the same letter in the column do not differ by Tukey test at $5 \%$ probability.

The results of the rupture modulus obtained are similar to those obtained by Lima et al. (2006) when evaluating panels of pinus elliottii agglomerates with inclusion of $30 \%$ of the babassu epicarp (20.03 MPa) and Iwakiri et al. (Virola surinamensis Rol. Warb), with average values of MOR of 27.04, in the case of wood panels from Amazonia: Rubber (Ecclinusa guianensis Eyma), Copaiba (Copaifera multijuga Hayne), Louro (Ocotea sp.) and Virola 23.05, 23.54 and 23.52 $\mathrm{MPa}$, respectively.

Regarding the modulus of elasticity, it is possible to verify that the results obtained in this study were superior to those presented by Trianoski et al. (2016) in particleboard of Grevillea robusta and Pinus taeda, (MOE of 1,173.01 $\mathrm{MPa}$ and 1,751.47 MPa, respectively) and particleboard of Eucalyptus urophylla and Schizolobium amazonicum (734 MPa and 1,873 MPa) (Naumann et al., 2008).

The obtained results are compatible with some residues and fibers indicated by researchers for use in particleboard, however, it is recommended for future formulations of scientific hypotheses: the need to circumvent the physical limitations of swelling in thickness and water absorption of panels to the base of babassu residue, to technically make feasible the use of babassu residue as the raw material for particleboard.

\section{Conclusion}

The babassu residue has technological characteristics that allow its use in particleboard, especially for its excellent mechanical performance, but there are particularities that can compromise its application, such as high silica content and high density. Particleboard made from babassu residue presented mechanical performance above that required by current normative documents. However, for the physical properties, especially for the porosity of the particleboard of babassu, the obtained values were lower than the required minimum

\section{References}

Almeida, R. R., Del Menezzi, C. H. S., \& Teixeira, D. E. (2002). Utilization of the coconut shellof babaçu (Orbignya sp.) to produce cementbonded particleboard. Bioresource Technology, 85, 159.163. https://doi.org/10.1016/S0960-8524(02)00082-2

Associação Brasileira de Normas Técnicas (ABNT). (2013). NBR 14810-2: Chapas de madeira aglomerada (pp. 28-30). Rio de Janeiro, Brasil.

Baldin, T., Silveira, A. G. da, Vidrano, B. R. A., Cancian, L. L., \& Haselein, C. R. (2016). Qualidade de painéis aglomerados produzidos com diferentes proporções de madeira e capim-annoni. Revista Brasileira de Ciências Agrárias, 11(3), 230-237. https://doi.org/10.5039/agraria.v11i3a5376

Belini, U. L., Savastano Junior, H., Barrero, N. G., SartorI, D. L., Leite, M. K., Fiorelli, J., \& Tomazello Filho, M. (2014). Painel multicamada com reforços de partículas de bambu. Scientia Forestalis, 42, 421-427. Retrieved from http://www.ipef.br/publicacoes/scientia/nr103/cap12.pdf

Bufalino, L., Abino, V. C. S., Sá, V. A., Correa, A. A. R., Mendes, L. M., \& Almeida, N. A. (2012). Particleboards made from Australian red cedar: Processing variables and evaluation of mixed species. Journal of Tropical Forest Science, 24(2), 162-172. Retrieved from https:/www.researchgate.net/ publication/286745004_Particleboards_made_from_Australian_red_cedar_Processing_variables_and_evalu ation_of_mixed-species 
Carvalho, A. G., Mendes, R. F., Oliveira, S. L., \& Mendes, L. M. (2015). Effect of Post-production Heat Treatment on Particleboard from Sugarcane Bagasse. Materials Research, 18, 78-84. https://doi.org/ 10.1590/1516-1439.270814

Composite Panel Association. (2009). ANSI A208.1: Particleboard standard (p. 9). Leesburg, EUA.

European Standards. (2003). EN 312: Particleboards-Specifcations (p. 22). Bruxelas, Bélgica.

Fiorelli, J., Christoforo, A. L., Lahr, F. O. R., Nascimento, M. F., Curtolo, D. D., Sartori, D. L., \& Belini, U. L. (2015). Painéis de partículas monocamadas fabricados com resíduo de madeira e fibra de coco verde. Scientia Forestalis, 43, 175-182. Retrieved from http://www.ipef.br/publicacoes/scientia/nr105/cap17.pdf

Fiorelli, J., Gomide, C. A., Lahr, F. A. R., Nascimento, M. F., Sartori, D. L., Ballesteros, J. E. M., ... Belini, U. L. (2014). Physico-chemical and anatomicalcharacterization of residual lignocellulosic fbers. Cellulose, 21, 3269-3277. https://doi.org/10.1007/s10570-014-0398-9

Fiorelli, J., Lahar, F. A. R., Nascimento, M. F., Sasvastano, H., \& Rossignolo, J. A. (2011). Painéis de partículas à base de bagaço de cana e resina de mamona_Produção e propriedades. Acta Scientiarum Technology, 33, 401-406. https://doi.org/10.4025/actascitechnol.v33i4.9615

Gatani, M., FiorellI, J., Medina, J., Arguelo, R., Ruiz, A., Nascimento, M. F., \& Savastano, H. (2013). Viabilidade técnica de produção e propriedades de painéis de partículas de casca de amendoim. Revista Matéria, 18, 1286-1293. https://doi.org/10.1590/S1517-70762013000200004

Instituto Adolfo Lutz (IAL). (1985). Normas analíticas do Instituto Adolfo Lutz. Métodos químicos e físicos para análise de alimentos (Vol. 1, 3rd ed.). São Paulo.

Instituto Brasileiro de Geografia e Estatística. (2015). Produção da Extração Vegetal e Silvicultura (pp. 30-33). Rio de Janeiro, Brasil.

Iwakiri, S., Shimizu, J., Silva, J. C., Del menezzi, C. H. S., Puehringher, C. A., Venson, I., \& Larroca, C. (2004). Produção de painéis de madeira aglomerada de Grevillea robusta A. Cunn. ex R. Br. Revista Árvore, 28, 883-887. https://doi.org/10.1590/S0100-67622004000600013

Iwakiri, S., VIanez, B. S., Weber, C., TrianoskI, R., \& Almeida, V. C. (2012). Avaliação das propriedades de painéis aglomerados produzidos com resíduos de serrarias de nove espécies de madeiras tropicais da Amazônia. Acta Amazônica, 42, 59-64. https://doi.org/10.1590/S0044-59672012000100007

Lima, A. M., Vidaurre, G. B., Lima, R. M., \& Brito, O. E. (2006). Utilização de fibras (epicarpo) de babaçu como matéria prima alternativa na produção de chapas de madeira aglomerada. Revista Árvore, 30, 645-650. https://doi.org/10.1590/S0100-67622006000400018

Machado, N. A. F., Kawabata, C. Y., Fiorelli, J., \& Savastano, H. (2015). Babassu husk fiber particleboard. In F. Lahr, J. Fiorelli, \& H. de Savastano (Eds.), Non-conventional building materials based on agro-industrial wastes (Vol. 1, pp. 233-248). Bauru, SP: Tiliform.

Maloney, T. M. (1996). The family of wood composite materials. Forest Products Journal, 46(2), 19-26. Retrieved from http://www.scielo.br/scielo.php?script=sci_nlinks\&ref=000138\&pid=S1516-14392013000 20002000015\&lng=en

Melo, R. R. (2013). Estabilidade dimensional de compósitos de madeira. Ciência da Madeira, 4, $152-175$. https://doi.org/10.12953/2177-6830.v04n02a03

Mendes, R. F., Mendes, L. M., Guimarães Júnior, J. B., Mori, F. A., \& César Silva, A. A. (2010). Efeito da incorporação de casca de café nas propriedades físico-mecânicas de painéis aglomerados de Eucalyptus urophylla S. T. Blake. Revista Ciência e Agrotecnologia, 34(3), 610-617. https://doi.org/10.1590/ S1413-70542010000300012

Motta, L. A. C., \& Agopyan, V. (2007). Caracterização de fibras curtas empregadas na construção civil (p. 23). São Paulo, Brasil. Retrieved from http://www.pcc.poli.usp.br/files/text/publications/BT_00450.pdf

Naumann, R. B., Vital, B. R., Carneiro, A. C. O., Della Lucia, R. M., Silva, J. C., Carvalho, A. M. M. L., \& Colli, A. (2008). Propriedades de chapas fabricadas com partículas de madeira de Eucalyptus urophylla S. T. Blake e de Schizolobium amazonicum Herb. Revista Árvore, 32(6), 1143-1150. https://doi.org/10.1590/ S0100-67622008000600020 
Paes, J. B., Nunes, S. T., Lahr, F. O. R., Nascimento, M. F., \& Lacerda, R. M. A. (2011). Qualidade de chapas de partículas de Pinus elliottii coladas com resina poliuretana sob diferentes combinações de pressão e temperatura. Ciência Florestal, 21, 551-558. https://doi.org/10.5902/198050983812

Park, B., Riedl, B., \& Kim, Y. S. (1998). Anatomical characteristics of wood fibers for medium density fiberboard (MDF) manufacture. IAWA Journal, 19(4), 472.

Queiroga, V. P., Girão, Ê, G., Araújo, I. M. S., Gondim, M. S., Freire, R. M. M., \& Veras, L. G. C. (2015). Composição centesimal de amêndoas de coco babaçu em quarto tempos de armazenamento. Revista Brasileira de Produtos Agroindustriais, 17(2), 207-213. https://doi.org/10.15871/1517-8595/rbpa.v17 n2p207-213

Silva, D. J., \& Queiroz, A. C. de. (2006). Análise de alimentos. Viçosa, MG: Editora da Universidade Federal de Viçosa.

Soares, S. S., Guimarães Júnior, J. B., Mendes, L. M., Mendes, R. F., Protásio, T, P., \& Lisboa, F. J. (2017). Valorização do bagaço de cana-de-açúcar na produção de painéis aglomerados de baixa densidade. Brazilian Journal of Wood Science, 8(2), 64-73. https://doi.org/10.12953/2177-6830/rcm.v8n2p64-73

Soler, M. P., Vitali, A. A., \& Muto, E. F. (2007). Tecnologia de quebra do coco babaçu (Orbignya speciosa). Ciência e Tecnologia de Alimentos, 27, 717-722. https://doi.org/10.1590/S0101-20612007000400007

Trianoski, R., Piccardi, A. B. R., Iwakiri, S., Matos, J. L. M. de, \& Bonduelle, G. M. (2016). Incorporação de Grevillea robusta na Produção de Painéis Aglomerados de Pinus. Floresta e Ambiente, 23(2), 278-285.2016. https://doi.org/10.1590/2179-8087.141515

\section{Copyrights}

Copyright for this article is retained by the author(s), with first publication rights granted to the journal.

This is an open-access article distributed under the terms and conditions of the Creative Commons Attribution license (http://creativecommons.org/licenses/by/4.0/). 